\title{
Dissecting and Constructing Magic in Greco-Roman Literature
}

When does a prayer turn into a curse? What is the difference between pious worship and manipulative coercion? Who ultimately draws the boundaries between magic and religion? When we consider the various connotations of magic in the context of Greco-Roman culture before the Common Era, we are faced with a twofold conundrum. The concept of magic is constructed, on the one hand, from the often-biased depictions of what the ancient authors judged to be magic and, on the other hand, from the varied approaches that modern scholars have used to study Greco-Roman magic. Yet, even though we have ample evidence on ancient practices that were widely considered to be magic, these practitioners seldom left any commentaries on their work. In this chapter, I will outline the development of magic as a concept within both the Greco-Roman literature and the scholarship discussing ancient magic. I do not aim to describe any actual magical practices; instead, I will concentrate on the discourse on magic - ancient and modern. ${ }^{1}$ First, I will briefly survey how the ancient concept of magic has been reconstructed in modern scholarship, and how it may have affected our understanding of the phenomenon. Second, I will consider various elements that Greco-Roman literati employed in crafting their definitions of magic.

\section{Greco-Roman Magic under a Scholarly Microscope}

Any endeavor to describe, analyze, or understand the ancient concept of magic requires a working definition of what exactly is considered to be magic. As such, magic is a notoriously elusive concept which is often talked about, but which seldom has clear definitions or unambiguous content that all parties would agree on. Some regard magic as a substantial phenomenon that has certain modi operandi, actual operational powers - whether they work for good or for bad - and tangible effects, while others use magic as a discursive concept that classifies and labels various practices. Therefore, it is important to clarify whose ideas of magic are being considered: are they those of ancient practitioners of 'magic,' for instance, people employing potions and spells for their own use or professionals offering their services for a fee, or those of educated literati, who often employed the term magic in a deprecatory sense? Or, are they perhaps those of modern scholars attempting to define magic from the perspective of their own cultural background? Furthermore, one needs to keep in mind that these ancient and modern contexts for definitions vary in different places and different times. Therefore, before surveying Greek and Roman views on magic, we need to consider how the etic perspective on ancient magic, that is, our modern concepts of magic which are projected on the

\footnotetext{
${ }^{1}$ See Gordon and Simón 2010, 5.
} 
ancient sources, have developed and shaped our understanding of Greco-Roman magic in recent decades.

Since ancient testimonia show that magic involved evocation, utilization, and even manipulation of superhuman $^{2}$ powers, a logical starting point for many scholarly constructions of magic has been its relationship to and distinction from religion. Perhaps the most influential scholars in this respect have been the two pioneers of anthropology, Sir Edward Burnett Tylor and Sir James George Frazer. They were both advocates of the nineteenth century ideas of cultural evolution, which led them to assign the practice of magic to less developed stages of societies. Tylor considered that all societies passed from savagery to barbarism and finally to a civilized state: and, in his view, magic belonged to the less educated and more primitive levels of development. ${ }^{3}$ Yet, evolution is not linear, and just as civilized societies can lapse back into more primitive forms of spiritualism, they have also preserved survivals of past ways through "stupidity and unpractical conservatism and dogged superstition." ${ }^{4}$ On the other hand, Tylor noted that all communities tend to associate magic with other groups that they consider more savage than themselves, ${ }^{5}$ which foreshadows the contemporary view on magic as an othering device. Tylor mainly viewed magic as a psychological tool that provided its practitioners with authority and prestige; when magic seemingly works, it is by pure chance or because of natural causes, while the magicians are skilled in finding excuses for their failures. Yet, Tylor does not label those practicing magic as impostors, since they rely on complex pseudo-scientific explanatory systems that are transmitted among fellow professionals. ${ }^{6}$

The opposing lines that Tylor draws between magic, religion (or "animism" as he calls it), and science are even more clearly presented in the evolutionary scheme of his follower, Sir James George Frazer. For Frazer, magic represents the lowest stage of cultural development, which will be replaced by religion and which will, in turn, give way to science. He believed this progress to be universal, so that the intellectually more primitive stage of magic use has preceded the development of religion in different cultures, even though they can still coexist. ${ }^{7}$ In his magnum opus, The Golden Bough, Frazer delineates the crucial differences between magic, religion, and science. While magic and science share the idea of a predictable world where the succession from one thing to a certain effect is fixed, magic essentially misperceives the laws that govern this succession. Thus, magic is fundamentally fallacious. On the other hand, magic and religion share the belief in superhuman force that either

\footnotetext{
2 To use the term "supernatural" would violate ancient understanding of natural world. See Martin 2004, 14.

3 Tylor 1891, 112-113, 138-141.

${ }^{4}$ Tylor $1891,156$.

5 Tylor 1891, 113-114.

${ }^{6}$ Tylor 1891, 133-135.

${ }^{7}$ Frazer 1900, xvi, 65-70, 77-78.
} 
directs the succession of things or intervenes in it, while their difference lies in the attitude towards these powers. Whereas religion seeks to plead to and placate superhuman agent(s) that are perceived as conscious and personal, magic strives to control and compel them. In other words, religion is reverential and submissive, magic in turn arrogant and coercive. ${ }^{8}$

The idea of the inherent immorality of magic has slanted the Western conception at least since late Antiquity, when the early Christian writers deployed the notion in a polemical sense against rival religious groups and practices. ${ }^{9}$ However, unlike Frazer's idea of magic as false science, the Christian writers considered the powers summoned by the magicians to be real and potentially effective - they were just deemed categorically wicked and immoral. ${ }^{10}$ A subtler variation of this view gained a footing in modern scholarship with Émile Durkheim's influential work The Elementary Forms of the Religious Life (first published in 1912 as Les formes élémentaires de la vie religieuse). Durkheim rejects Frazer's distinction between magic and religion and the antecedence of magic: instead, he considers that magic is born of religion. According to Durkheim, magic and religion are parallel phenomena, and the forces that they appeal to, as well as the rituals they employ such as prayers and sacrifices, are often indistinguishable. The core of religion, however, is the moral community - the church as Durkheim calls it - that brings a group of people together and binds them to a conception of moral life. Magic, in its turn, lacks communality, it profanes the sacred and contradicts religious ceremonies. ${ }^{11}$ Thus, magic is asocial and amoral, if not outright immoral.

Subsequent generations of anthropologists have criticized the late nineteenth and early twentieth century tendency to view empirical data from an inescapably Western standpoint, and the attempt to fit the findings to a preconstructed theory without incorporating sensitivity to indigenous cultural meanings. Consequently, the use of the essentially etic notion of "magic" - and its supposed categorical opposition to an equally problematic notion of "religion" - has been problematized; the concept of magic has been viewed as a modern Western construct that is biased and thus ill-suited for

\footnotetext{
${ }^{8}$ Frazer 1900, 61-64. The noted sociologist William J. Goode associated similar characteristics with the ideal type of magic, which would tend towards instrumental value, personal goals, and the individual rather than activity that is marked by a manipulative attitude. Nonetheless, he acknowledged that, in real life, the supernatural systems of different cultures most often fall somewhere between the theoretical poles of pure religion and pure magic. See, e.g., Goode 1951, 50-55.

${ }^{9}$ See, e.g., Kahlos 2015. Certainly, the label of magic had served as a handy hobby horse in earlier disputes on religious authority as well, but often - even though not always - the emphasis was either on the ineffectiveness of the alleged magical rituals or on the malicious intentions of their practitioner, not on the evilness of the rituals or the conjured forces as such.

${ }^{10}$ E.g., August. De civ. D. 8.19. See also Sanzo 2019, 228-229; on the demonization of Greco-Roman divinities, see Kahlos 2007, 173-174.

${ }^{11}$ Durkheim 1915, 42-47, 182, 361-362, 418-420. The eminent anthropologist Bronisław Malinowski praised the work of Frazer, even though his own emphasis on the communality of religion and instrumentality of magic approaches Durkheim's definition. According to Malinowski (1948, 20-24, 48-50, 55-70 and passim), magic serves as the means to achieve a specific end according to its own prescribed techniques, while religion is embedded in the traditions of the community and functions as a basis for moral control.
} 
the study of other cultures. ${ }^{12}$ Nonetheless, the assumed dichotomy between magic and religion has been particularly influential for the study of Greco-Roman magic. It has proved difficult, if not even impossible, to escape our understanding of religion as a point of reference when discussing the phenomenon of magic in antiquity. ${ }^{13}$ This juxtaposition is justified to some extent. If we consider the situation in ancient Greece and Rome, "magic" would not have been an unfamiliar concept, as we shall see below, and it was firmly located in the same semantic sphere as sacred matters that have since been termed religious. Yet, since the idea of religion as a separate sphere of human activity did not exist in the Greco-Roman world, any strict separation between magic and religion is necessarily artificial. $^{14}$

Recent advances in the scholarship on ancient Greco-Roman magic have invoked an awareness that the difference between what was understood as magic and other forms of religious life in antiquity rested neither on the attitude towards them, nor on the ritualistic means and ends involved but rather on social context and approval. ${ }^{15}$ Therefore, many scholars have chosen to investigate certain ritual practices such as potions, amulets, spells, curses, and necromancy as manifestations of ancient magic, whether they were in their own context thus identified or not, ${ }^{16}$ thus following an etic approach. On the other hand, other scholars have expressly targeted the ancient discourse on magic, thus aiming to discern under what circumstances certain practices became viewed with suspicion, if not even denunciation, and what connotations the label of magic entailed at a given time. ${ }^{17}$ This also includes the question of the criminalization of magic; that is, whether there were actual laws against magical practices, and how a lawsuit against magic would be charged or defended in the court. ${ }^{18}$ The focus on the discourse of magic emphasizes the subjectivity of any definitions of magic, and even questions whether we can objectively identify any practices that would fall under that label. Furthermore, this approach brings to the foreground the public and often also very personal motivations for the

\footnotetext{
${ }^{12}$ See, e.g., the reviews of Wax and Wax 1963 (including comments from other scholars); Versnel 1991b, 179-181, 184187. The binary opposition between "magic" and "religion" is one of the bases that prompts Otto (2013, esp. 321 n. 55) to argue that the category of magic ought to be discarded in the study of Antiquity; see, however, Sanzo's (2020) wellgrounded discussion on the shortcomings of the deconstructionist approach.

${ }^{13}$ For instance, Versnel (1991b, 187; see also Fowler 2000, 321) promotes religion "as one obvious model of contrast" to magic. For further references, see Graf 2003, 207-208 ns. 3-4, 7. For a review of how anthropological theories have contributed to the understanding of how ancient magic worked, see Collins 2008, 3-24.

${ }^{14}$ Many scholars have pointed out that the elements traditionally labeled as "religious," such as establishing a submissive, reverent, and reciprocal relationship to the divinity in question, or finding justifications for one's requests, are often also found in texts that are categorized as magical. See, e.g., Graf 1991, 189-197; Versnel 1991a. See also the discussions of Remus (1999) and Sanzo (2020). On the caveats of emic and etic approaches to "magic," see also Frankfurter 2019, 3-7, $10-12$.

${ }^{15}$ E.g., Fowler 2000, 318, 323, 343.

${ }^{16}$ E.g., Collins 2008.

${ }^{17}$ E.g., Stratton 2007.

${ }^{18}$ E.g., Kippenberg 1997.
} 
accusations of magic, and thus reveals underlying social tensions and power struggles as well as culturally sensitive notions of belonging and otherness. The acknowledgment that magic is ultimately a social construction that rests upon relative and altering interpretations and argumentation does not, however, mean that we should abandon the materiality of Greco-Roman magic. As Kimberly Stratton $(2007,11)$ points out "once the concept [of magic] exists in a particular culture, it acquires power, forever altering the way certain practices or people are viewed. [...] Once an idea of magic does exist, it wields social power - it becomes 'real' for people who believe in it." In other words, even though the understanding of what comprises magic is mutable and capricious, the mere act of categorization and naming renders the practices in question magic for those who subscribe to that view. Before delving into various Greco-Roman definitions of magic, it is important to bear in mind that even though our extant sources often give a rather uniform image of magic, magicians, and their social marginality, it does not mean that the dominant discourse that they deploy for their own ends - and help to cement for their part - would have been the only one. On the contrary, various views on magic and its efficacy lived side by side, sometimes colliding, sometimes coalescing with each other.

\section{Eastern Magic and Feminine Witchcraft - Marginalizing Magic}

The word magos, from which the later English terms for magic and magician stem, was the technical term for Persian fire priests. The first reference to magoi in Greek sources comes from a fragment attributed to the late sixth and early fifth century BCE philosopher Heraclitus of Ephesus. In a rather sullen tone, Heraclitus (DK 22 B 14 = Clem. Alex. Protr. 2.32) comments on night-roamers, magoi, bacchants, maenads, and those who were initiated into mysteries threatening them with posthumous torment. Even though the mention of magoi (plural of magos) might be a later interpolation, the fragment and the criticism it exhibits is generally considered to be genuine. ${ }^{19}$ In Heraclitus' time, his Ephesian homeland had been under Persian dominion already for a few decades, which makes it probable that Heraclitus was aware of the fire priests and, in that context, they would have represented the foreign occupiers. ${ }^{20}$ Not only does Heraclitus depict magoi in a negative light, he also associates them with shady nightly activities and mystery initiations that are performed profanely. In other words, the magicians proper were from the start associated with potentially hostile Eastern powers and secret rituals that had a markedly suspicious character.

\footnotetext{
${ }^{19}$ See, e.g., Graf 1997, 21-22; Graf 2019, 117; Bremmer 1999, 2-3; Dickie 2001, 28-29.

${ }^{20}$ Cf. Graf 2013: 145: "[magoi] were well-known and feared, hated, or despised in Persian-occupied Ephesus of Heraclitus' time."
} 
The fifth-century BCE historian Herodotus mentions Persian magoi several times in his description of the Eastern adversary of the Greeks. ${ }^{21}$ Herodotus marvels at the traditions of the magoi that are related to the treatment of the dead and the killing of animals (1.140); he also notes that the presence of a magos is required whenever the Persians offer a sacrifice (1.132). According to the historian, the magoi read omens, and some of them are specialists in dream interpretation. It is in this capacity that Herodotus describes their proximity to the Median and Persian rulers, who often consult them (1.107$108,120,128 ; 7.19,37)$. Herodotus also relates that King Cambyses had left a magos by the name of Patizeithes as the overseer of his house during his campaign in Egypt. A plot, however, allowed the magos to raise his brother to the throne during Cambyses' absence, and a coup was needed to overthrow the brothers. According to Herodotus, this resulted in a massacre of the magoi, which was commemorated annually (3.61-79). In addition to sacrificing to the gods, Herodotus also ascribes to magoi activities that his contemporary Hellenes would have recognized as magic, that is, an attempt to affect the winds by offering sacrifices and singing incantations (7.191, cf. 1.132.3). Furthermore, their practices acquire a truly sinister tone, as Herodotus recounts how the libations that the magoi offered to the heroes at Ilion summoned nightly terrors to haunt the enemy camp (7.43), how they used enchantments and sacrificed white horses to receive good omens at the river Strymon and, after crossing the river, buried alive nine boys and nine girls from the local inhabitants (7.113-114). ${ }^{22}$

The obvious problem when one discusses ancient Greek conceptions of magic, however, is that there was magic before "magic." In other words, various ritualistic practices that later became part and parcel of the understanding of what comprises magic existed under many different names, practiced by individuals variously identified, long before the word magos and its cognates found their way to Greek. $^{23}$ These included the epôdoi and goêtes, whose names suggest that their expertise lay originally in the singing of incantations that were intended for healing or guiding the spirits of the dead, as well as the pharmakeis or female pharmakides, who derived their title from the use of drugs (pharmaka). By the late fifth century BCE, all these designations could be used rather interchangeably

\footnotetext{
${ }^{21}$ Even though in Latin literature magus and its derivates were used more frequently in the general sense to refer to magic and magicians, the particular meaning as Persian priests could also be evoked. See, e.g., Cic. Leg. 2.26; Apul. Apol. 25. See also Collins 2008, 61.

${ }^{22}$ See also Collins 2008, 56-57; Dickie 2001, 33-34, Ogden 2008, 24. A further note of disapproval and outrage is added by another contemporary Greek historian, Xanthus of Lydia, who relates that the magoi accept incestuous relations with mothers, daughters, and sisters, and consider it appropriate for men to share a wife. FGrHist 688 F 1 (= Clem. Al. Strom. 3.11). This piece of information may have also triggered Catullus' (90) waspish comment that the abominable union of Gellius with his mother would produce a Magus.

${ }^{23}$ Cf. Gordon 1999, 178. The Greek understanding of what could be labeled magic in etic terms included practices such as divination and shape-shifting, the performance of incantations, purifications, and initiation rituals, the ability to conjure spirits of the dead, and manipulate the elements and celestial bodies as well as affect one's erotic urges and lifespan. See Ogden 2008, 22-25; cf. Graf 1997, 26-27.
} 
to refer to the practitioners of magic. ${ }^{24}$ Even the Homeric hero Odysseus was faced with Circe's powerful potion, which had the potency to transform him and his men into pigs, and Odysseus was only saved by the intervention of Hermes, who offered a protective herbal remedy; both of these are identified as pharmakon, a word that was indivisibly linked with magical practices by the Classical period. ${ }^{25}$ Furthermore, having learnt from Circe how to proceed, the astute hero makes his way to the underworld, where he summons the souls of the dead and the spirit of the seer Tiresias in particular, in order to gain knowledge otherwise hidden from him. ${ }^{26}$ Thus, the earliest Greek literary work already presents the sinister side of magic, with the ability and will to harm others and the potency to raise the dead, embodied in the character of the designing goddess Circe, as well as the benign, protective magic, which is associated with the Olympian gods and their powers. ${ }^{27}$ Furthermore, the two central elements that will dominate the Greco-Roman descriptions of magic in the following centuries are also present in the Homeric epic: on the one hand, magic is associated with the feminine faculties, cunning, and vileness, on the other hand, magic represents power that belongs to distant, marginal, and liminal spaces. Next, I will shortly discuss these aspects in the literary sources before the Imperial era.

By the fifth century BCE, the conceptual distance associated with magical practices was incorporated in the emerging image of the Barbarian East. As Heraclitus' usage of the Persian-origin magoi to refer to night-roaming advocates of private mystery cults illustrates, various religious practices and practitioners that were not related to the polis structures had started to intermingle already before the fifth century BCE. While Homeric sources can still describe the abilities of the Olympian gods in terms of herbal magic and commend foreign religious experts (Hom. Od. 17.384-387), the association of these unendorsed practices with religious experts of a peculiarly Eastern flavor would become one of the first steps in the notional separation between proper ancestral religion and illicit foreign magic. A crucial factor in this development was the emergence of the image of the inferior barbarian Orient that, above all, was forged in the Athenian public discourse as a result of the city's newly acquired status as the champion of the Hellenic freedom and valor. ${ }^{28}$

\footnotetext{
${ }^{24}$ See, e.g., Dickie 2001, 12-15; Stratton 2007, 27-30; Graf 1997, 27-29; Ogden 2008, 3; Collins 2008, 60-61. For the development of equivalent terminology in Latin, see Stratton 2007, 30-34; Gordon 1999, 165.

${ }^{25}$ Hom. Od. 10.213, 287, 290, 292, 302, 326-327. Cf. Hom. Od. 4.219-232 where Helen mixes with wine a powerful drug she has acquired from Egypt. See also Ogden 2008, 11, 15-20; Collins 2008, 27-28.

${ }^{26}$ Hom. Od. $10.504 \mathrm{ff}$.

${ }^{27}$ See also Hom. h. 2.227-230, where the goddess Demeter in her disguise as a nurse declares that she knows the ways to protect an infant from harmful magic, and Collins 2008, 29-30. Cf. Pind. Pyth. 4.213-218, where Aphrodite teaches the hero Jason how to use a love-charm, incantations, and prayers to entrap his love-interest.

${ }^{28}$ See esp. Stratton 2007, 40-42; cf. Gordon 1999, 163 and Bremmer 1999, 6-8, who suggests that itinerant magoi, who were active in the Greek world in the late fifth century, contributed to the semantic shift from Magi to the generalizing concept of magicians. On the development of the discourse of barbarism on the Athenian public stage, see Hall 1989.
} 
As a result, the public media of the day, drama, consistently associates magical practices with barbarians. In his Persians, the tragic poet Aeschylus depicts Queen Atossa as seeking counsel from her late husband, the Great King Darius, whom she conjures from the netherworld by pouring libations to the dead and the chthonic gods while the Persian elders chant hymns and call on Darius' spirit with barbaric cries (607-639). Thus, Aeschylus accredits the Persians with unconventional religious customs decades before Herodotus' description, even though he is apparently unaware of the priestly group of magoi. ${ }^{29}$ In the second half of the fifth century, the playwright Euripides employed the cognates of magos in several tragedies to create an image of strange barbarian practices. When the Greek heroine Iphigenia is hurled into the distant land of the Taurians, she deplores the barbaric practices, including human sacrifices, that she is forced to conduct as a priestess. When Iphigenia is plotting to escape with her brother, she tries to convince the Taurians that she is performing a purificatory ritual. Thus, she "chanted barbaric incantations using magic arts." ${ }^{30}$ Apparently, Iphigenia, along with Euripides' Athenian audience, expected the Taurians to perform rituals in that way. In Euripides' Orestes, a Phrygian slave, a paragon of cowardly barbarians, explains Helen's sudden disappearance either by a magic potion, magicians' crafts, or the gods' secret acts. ${ }^{31}$ Again, a barbarian character is expected to rationalize an unexpected event primarily in reference to magic; on the other hand, the magicians' art seems somewhat separate from the workings of the gods. In his last play, The Bacchae (234), Euripides closely associates wizards and sorcerers with Eastern religious figures. His choice of words, goês and epôdos instead of magos, suggests that different terms had become interchangeable expressions for an itinerant practitioner with an unmistakably Eastern aura by the end of the fifth century.

Whereas the hostile image of the East lent magic a depreciative undertone during the Classical period, the geopolitically altered situation was reflected in the Greek perception during the Hellenistic period. As the Greeks conquered the old Persian and Mesopotamian dominions, they no longer posed a threat and, while the Orientalizing image of inferiority did not vanish, it was replaced by an inquisitive interest, which saw more possibilities than risks in the East. Thus, Eastern magic was not only suspicious but also powerful, and Eastern magicians could represent figures of greater knowledge and authority. For instance, an Assyrian expert provided Theocritus' amateur witch Simaetha with her most powerful and deadly potions; the idyll also illustrates how the imaginary realm of magic has

\footnotetext{
${ }^{29}$ Aeschylus (Pers. 317) mentions Magos Arabos as one of the dead Persian commanders, which suggests that Aeschylus knew magos as a proper noun. See Bremmer 1999, 3-4.

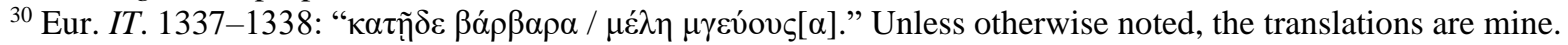

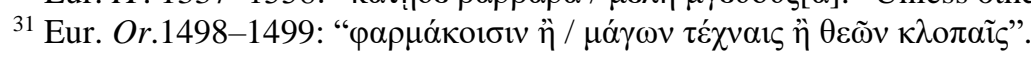


expanded from Persia to Syria, Babylonia, Chaldea, and beyond. ${ }^{32}$ In his description of the Eastern Empires, Diodorus Siculus remarks favorably on the Chaldeans' artistry in divination and incantations, both of which have the power to avert evil and bring about fortunate outcomes; the Chaldeans' commitment to their studies is paralleled with philosophical inquiry. ${ }^{33}$ Even though Diodorus' exodus is a short one, some Hellenistic literati apparently devoted great efforts and extensive works to recording Eastern lore. ${ }^{34}$ Even though the Latin words magus and magicus did not see daylight before the last decades of the Republic, ${ }^{35}$ the idea of magical practices as a distinctive category of religious practices, that are beyond or even contrary to ancestral traditions, appears in the writings of the second century BCE. The Romans adopted the Greek conception of the Eastern origins of magic, and the Chaldeans were tantamount to astrologers and magicians already in the second century BCE. ${ }^{36}$ On the other hand, the mighty witch that Dido describes in Vergil's Aeneid (4.480483) resides on the edge of the world. In addition, the Romans readily associated magical practices with their neighboring peoples, such as the Marsi or the Sabellians, as well as the northern druids. ${ }^{37}$ In other words, for the Romans, too, magic connoted ethnic otherness.

Another aspect of otherness has arguably been part and parcel of the Greco-Roman perception of magic even longer than foreignness, namely femininity. Daniel Ogden has argued that the characters of Homeric Circe and Colchean Medea, which had also been developed before the Classical period, demonstrate that, in the first instance, the Greeks associated magical practices with female witches, and the emergence of the male magos was a later development. ${ }^{38}$ The image of feminine magic that was already present in the earliest epic was further exploited and distributed in the drama. The mythical sorceress Medea featured in several tragedies, the most famous of which is Euripides' Medea, which was first staged in 431 BCE. Although magic is not foregrounded in Euripides' rendering, a messenger relates a gruesome description of how the poisonous cape and golden crown, which Medea had sent to her rival Creusa, melted the meat off of Creusa's bones and scorched her;

\footnotetext{
32 Theocr. Id. 2.161-162. See also Dickie 2001, 109-110; Ogden 2008, 86.

${ }^{33}$ Diod. Sic. 2.29. Diodorus relies on the earlier account of the Stoic philosopher Posidonius (ca. 135-51 BCE). See also Dickie 2001, 111.

${ }^{34}$ Plin. NH 30.2. On the learnt Greek collections of magical knowledge, see Dickie 2001, 117-123; see also Gordon 1999 , 229-231, where he argues that the understanding that magic is an unacceptable and distorted form of religion precisely because it is of non-Greek origin was crystallized in the Hellenistic period.

${ }^{35}$ It appears that the noun magus retained the meaning of a Persian religious specialist well into the Common Era, whereas the adjective magicus covered a wider semantic field of the marvelous. On the development of the terms in Latin, see Rives 2009.

${ }^{36}$ See, e.g., Cato, Agr. 5.4; Val. Max. 1.3.3. On the origins of magic, see Pliny, HN 30.2.

${ }^{37}$ E.g., Plin. $H N$ 28.4, 30.4; Gordon 1999, 165.

${ }^{38}$ Ogden 2008, 21-35. Ogden (2008, 76-77) also points out that the developed image of a male sorcerer does not appear in Roman literature before the Common Era. See, however, Pind. Pyth. 4.213-218, where Medea herself is the victim of Jason's newly acquired love spells; see also Graf 2019, 220-221.
} 
even Creusa's old father suffered the same fate when he tried to embrace his daughter. Euripides' Medea herself says that she takes pleasure in their torment. ${ }^{39}$ Medea also appeared in three Sophoclean tragedies, of which only some fragments survive. The most interesting is Rhizotomoi or Root-Cutters, which represents Medea as practicing magic and apparently plotting to destroy King Pelias by convincing his daughters to boil him alive, giving the impression that this would restore his youthfulness. The title denotes those who collect magical plants, and a surviving fragment also depicts Medea as harvesting lethal herbs. ${ }^{40}$

Just as Medea's horrendous acts are described as welling out of her love, jealousy, and desperation, these motives assumedly drove other women, too, to resort to magic. ${ }^{41}$ Sophocles' Trachinae (see esp. 531-587, 672-722, 756-806) introduces us Heracles' wife Deianeira, who worries about her husband's constant absence and is devastated upon learning that Heracles has besieged an entire city because of his infatuation with young Iole. Deianeira decides to resort to a love philter, which she believes will win back her husband's affection. ${ }^{42}$ She sends a cloak smeared with the potion to Heracles, only to discover that the centaur Nessus, who had told her about the philter, had deceived her: the poisonous cloak injures Heracles so severely that he prefers to die. Female jealousy also instigates accusations of magic in Euripides' Andromache (32-35, 157-160): Hermione claims that Andromache is using secret philters to make her childless and objectionable in her husband's eyes. After the Trojan war, Andromache had ended up as the slave of Achilles' son, Neoptolemus, and bore him a son; thus, Neoptolemus' bride Hermione accused her of wanting to take her place by using the special skills of Asiatic women, that is, magical crafts. Similarly, Euripides' hero Ion deplores the destruction and slaughter that women cause men with their lethal philters ( $\varphi \alpha \rho \mu \alpha ́ \kappa \omega \nu \tau \varepsilon \theta \alpha v \alpha \sigma i ́ \mu \omega v)$. Shortly after this, the childless Creusa plots to kill Ion with a drop of Gorgon's blood that has miraculous powers, believing him to be her husband's biological son. ${ }^{43}$ Thus, feminine envy and jealousy is again depicted as a driving force behind women's calamitous experiments with drugs, even though Creusa's misgivings prove wrong in the end.

\footnotetext{
${ }^{39}$ Eur. Med. 1127-1135, 1156-1221; cf. 714-718. See also Ogden 2008, 33; Dickie 2001, 93-94; Stratton 2007, 51-54. The productive Greek playwright Neophron also wrote a tragedy titled Medea.

${ }^{40}$ Tragicorum Graecorum fragmenta (TGF) 4 F 534-536; Macrob. Sat. 5.19.9-10. See also Scarborough 1991, 144; Ogden 2008, 33; Dickie 2001, 94; Gordon 1999, 180. Medea's devious plan to revenge Pelias was also the subject of Euripides first play Peliades (455 BCE), and the story is elaborated in Diod. Sic. 4.50-52.

${ }^{41}$ Cf. Stratton 2007, 58, 61.

${ }^{42}$ See also Stratton 2007, 54-57; Gordon 1999, 196-197. The idea of associating desperate love and female magic is also reflected in the Roman rendering of epic heroines. When Vergil's Dido learns that Aeneas is resolved to sail on despite their love affair, she plays with the idea of resorting to magic in order to win him back or be freed of her love (Verg. Aen. 4.478-493).

${ }^{43}$ Eur. Ion 616-617, 998-1038.
} 
It is notable that, in addition to the repeated association of women with magic in Greco-Roman literature, the magic practiced by women is often depicted as having - even when pursued with good intentions - internecine effects. Furthermore, the perception of women as inclined to excessive emotionality and unbridled sexuality, combined with their assumed inability to control their impulses, further contributed to the image of the innate femininity of magic. As Kimberly Stratton (2007, 6468) has pointed out, a society where men's status may be impugned based on the suspected probity of the women in their family tends to associate elements of danger and impurity with women. The concerns of the Athenian men were further exacerbated by the Periclean citizenship law of 451/0, which provided that the mother of a citizen also needed to be Athenian. Once the wedded wife was the only means of producing legitimate children, control over her sexuality became an ever more pressing matter. The tragic tales of women who brought about the destruction of their houses may reflect this anxiety, and magic was an apt addition to women's alleged subversive faculties. ${ }^{44}$ Furthermore, the association of magic with the feminine also reinforced the image of magic as subversive and belonging to the natural realm, ${ }^{45}$ and thus working against the civilized, male-based social order.

The literary portrayal of love spells as the height of feminine vileness epitomizes the subversion inherent in magic: not only are women thus portrayed as the active party in the relationship, but they also seek to subject their social superiors, men. ${ }^{46}$ Whereas the witches of early Greek literature are mythological figures, in the Hellenistic and Roman world the female practitioners of magic become more tangible. Even though they are still literary figures that mainly reflect male concerns and anxieties, they enter the world of their audiences' everyday experience. One of these contexts was the apparent male fear that they might lose their position of control as a result of their various extramarital liaisons. Women of low social status, such as courtesans or their procuresses, were readily suspected of trying to entice and manipulate men to improve their own lot in life. ${ }^{47}$ One of the most famous witches of Greek literature, Simaetha, the protagonist of Theocritus' second Idyll, is such a

\footnotetext{
${ }^{44}$ Since the birthing chambers were a female domain, further apprehensions may have arisen from the conditions surrounding delivery. As Plato's Socrates records that midwives use drugs and incantations to release labor pains, he adds that they may also use them to make the childbirth more difficult or cause a miscarriage. Pl. Tht. 149c-d.

${ }^{45}$ On the connection between the witches of Greek and Roman literature and nature, animals, and the corporeal, see Spaeth 2014, 43-46.

${ }^{46}$ Cf. Spaeth 2014, 44-45. The literary image of female love magic has proved so compelling that some scholars have tried to find a way around the material evidence, which primarily points to the male production and practice of love magic (Stratton, 2014a, 4; see also Eidinow 2019, 756-757). On the social and gender dynamics at play in the practice, as well as the representation of erotic magic, see Graf 1997, 185-190; Winkler 1991, 225-228, 232-233.

${ }^{47}$ E.g., Isae. 6.21. David Frankfurter (2014) deduces from the material evidence that women employed love magic primarily with the aim of securing their social and economic status. On the association between love magic and prostitution, see the discussion of Dickie (2001, 83-91, 164-165, 176, 178-184), even though he often fails to make a distinction between literary representations and social reality. Cf. Stratton 2014a, 4; Frankfurter 2014, 321-322.
} 
flesh and blood character. The third-century BCE portrait no longer centers around the destruction of a household or the broader social order, but instead focuses on the emotional tumult of a young Coan girl, who pines after her indifferent beloved Delphis. ${ }^{48}$ As Simaetha prepares a complex fire spell to draw Delphis back, she is entirely driven by her emotions, which fluctuate between hopefulness and despair. She evokes, among others, Hecate, the dreadful goddess of the dark moon, crossroads, and magic, ${ }^{49}$ and she ends her tirade by stating that if magic arts will not bring Delphis back, she is prepared to kill him with her potions.

Despite Simaetha's self-interested magic-working and deadly intents, Theocritus portrays her as young and attractive; the Roman image of an archetypical witch that originates in the late-Republican literature is quite the opposite. This so-called night-witch is a nightmarish, demon-like figure whose grotesque looks are matched only by her stomach-turning acts. Even though we might consider Lucan's first-century CE portrayal of blood-lusting and grave-desecrating Erichtho as the culmination of this topos, ${ }^{50}$ it is clearly visible already in the preceding century. Let us take a closer look at two examples, Ovid's Dipsas and Horace's Canidia with her companions. Ovid's Dipsas is a repulsive old sot who is trying to pull down a few coins by procuring a young woman. Ovid's alter ego is seemingly awestruck as he describes the deeds she is able to accomplish by magic: she can concoct poisons, split boulders with her incantations, raise corpses from their tombs, reverse the stream of rivers, command the weather, and turn the stars and the moon bloodstained; yet, as the narrator voices his suspicion that the feathered hag flutters about through the shadows, there is an unmistakable comic tone to it. ${ }^{51}$ Moreover, the poem leaves the reader wandering weather such a mighty sorceress would need to rely on a young girl's beauty to earn her meagre living. Thus, magic appears at the same time abhorrent, foul, socially low - and empty bluster.

In his fifth epode, Horace recounts how a company of witches is burying a young boy alive so that, after he has withered to death, they can harvest his organs for philters. Like Ovid, Horace also draws attention to the aged witches' repugnant looks, which are topped off by their bestial hairdos: Canidia has vipers in her hair, while Sagana's hair sticks out like a sea urchin or the bristles of a wild boar (4, 15-16, 27-28). Their cruel and abominable ceremony is incented by their unnatural lust, as their

\footnotetext{
${ }^{48}$ See also the adaptation of Vergil ( $\left.E c l .8 .64-109\right)$. Cf. the third-century BCE description of Medea by Apollonius of Rhodes (Argon. 3.284 ff.): Apollonius' Medea is a trembling maiden at the mercy of her ardor for Jason, and the poet can praise her beauty and graciousness in the same breath as he alludes to her scavenging of corpses and lethal herbs (Argon. 4.43-53). Graf (1997, 176-185) discusses the ritual actions that Theocritus describes in the Idyll.

${ }^{49}$ The first literary reference to Hecate as the mistress of witches is in Sophocles' Rhizotomoi (TGF 4 F 535).

${ }^{50}$ See, e.g., Spaeth 2014, 47-48, 50-51; Graf 1997, 190-191; Stratton 2014b, 152.

${ }^{51}$ Ov. Am. 1.8.5-18. The assumed ability to pull down the moon and control the weather were also stock features in the descriptions of Greek witches. See, e.g., Ar. Nub. 749-752; Hippoc. Morb. sacr.1. Cf. Hor. Ep. 5.45-46; 17.4-5, 76-80.
} 
philter is meant to draw Canidia's old and aberrant paramour Varus back to her bed (61-82; cf. 41). Besides the unfortunate boy's liver and marrow, Canidia's potions require an array of disgusting ingredients (17-24). Canidia and Sagana also make their appearance in Horace's satire (1.8), where a wooden statue of Priapus, who guards the former burial ground for the poor, complains about the witches that haunt the neighborhood in their search for body parts and herbs. Horace gives a vivid description of the pale witches evoking goddesses of the underworld, conjuring up ghosts, scratching the ground with their nails, and tearing an ewe apart with their teeth (23-45). But this grisly scene turns comic, subjecting the witches to ridicule and scorn, as the sound that the wooden Priapus statue discharges scares the witches so that they run back to the town, dropping their magical supplies along with their artificial hair and dentures $(46-50) .{ }^{52}$

These malevolent and monstrous Roman witches have come a long way from the passionate Greek underhanded poisoners. ${ }^{53} \mathrm{We}$ may surmise that the aggravated image of feminine magic in late republican Rome was the result of many factors. On the one hand, the wicked and ungodly witch embodied the moral and religious anxieties of the civil war age, when it seemed that all propriety had been lost and the gods had abandoned the Romans. ${ }^{54}$ The reason why these apprehensions took a feminine form is again connected with the central role that both Greek and Roman societies assigned women in the enshrinement of morality. Even though the real concern may have been men's fear of losing their dominant masculinity and its concomitant social status due to increasing female liberty and influence, the worries took the literary form of women behaving badly. ${ }^{55}$ In addition, the more threatening image of Roman witches compared to their Greek counterparts may result from the more marginal religious role and the more powerful social and economic potency that Roman women yielded, thus fueling chimaeras of women acquiring illegitimate religious power and turning the world upside down. ${ }^{56}$ In any case, Roman literature left a lasting imprint on the western imagination, that is, the incarnation of magic as a repugnant and malicious female figure. Just like the stereotype of wandering Eastern magoi, the stereotype of witches, who aim at reversing the social order, produced a strong marginalizing effect. The association of magic with suspect foreignness and femininity made practices that probably were ubiquitous in all walks of Greco-Roman life appear peripheral.

\footnotetext{
52 See also Dickie 2001, 179-181; Stratton 2007, 80-83; Ogden 2008, 46-50.

${ }^{53}$ See the discussion of Spaeth 2014, 46-50.

${ }^{54}$ Gordon 1999, 207-208.

${ }^{55}$ Stratton 2007, 71-79, 84, 93-99; Spaeth 2014, 54-56.

${ }^{56}$ Spaeth 2014, 53-54.
} 


\section{Impious, Dangerous, and Ineffective - Contesting Magic}

In addition to its marginalizing tendency, another major theme in the Greco-Roman magic discourse is confrontational argumentation that associates magic with illegitimate religious knowledge, and seeks to discredit certain ritual practitioners as avaricious impostors or harmful atheists. The images of foreign and feminine magic often intersected with those of danger, or of mere eyewash confirming the desired effect. Before surveying the limits of acceptable religious knowledge in literature, I will briefly discuss how magic was treated in Greek and Roman legislation and forensic practice.

In ancient Greece, no particular law prohibited practices that might be considered magical. Most of our evidence comes from Athens, where - as in Greek poleis in general - laws tended to be ambiguous about what exactly constituted a crime. Thus, what counted as punishable practices would be decided on a case to case basis, based on the argumentations of the plaintiff and the accused. Insinuations of magic were in any case an apt implement in trying to incriminate someone, thanks to the vagueness of the concept and the strong negative imagery attached to it. If someone had suffered a tangible harm on account of suspected magic, it would have represented the grounds for a trial. Whereas a love philter that turned out to be a lethal concoction presents a clear causal effect, ${ }^{57}$ in most cases it might have been difficult to prove that some spell or ritual was the actual cause of the damage. On the other hand, the charge of impiety (graphê asebeias) could cover anything that was considered to displease the gods, and thus endanger the community's good relations with the divine powers. If argued persuasively, magical practices might count as dangerous irreverence. ${ }^{58}$ The well-known legal action against the Lemnian herbalist and magic worker Theoris in fourth-century Athens successfully amassed evidence against her and earned her a death penalty. The roughly contemporaneous speech Against Aristogiton refers to Theoris as a pharmakis who was executed along with her entire family. Yet, even in this case, the dispensing of potions and spells alone did not constitute a crime, since Theoris' servant had delivered her drugs and charms to Aristogiton's brother, apparently without any disturbance. ${ }^{59}$ Yet, as Plato suggests (Meno 80a-b), allegations of magic might be treated more severely in other city-states: as Socrates' words have left Meno speechless, he compares the effect to

\footnotetext{
57 The fifth-century orator Antiphon (1.14-20) relates that a slave who had accidentally poisoned her master with what she believed to be a love philter was deservedly tortured and executed; in contrast, Aristotle (Mag. mor.1188b30-35) claims that the Areopagus court that decided murder cases at Athens had acquitted a freeborn woman whose love philter had similarly backfired, on the grounds that she had had no intention to kill. See also Gordon 1999, 249; Collins 2008,135136. Cf. the case referred to by Josephus (BJ 1.30.583).

${ }^{58}$ See the discussions of Gordon 1999, 244-250; Collins 2008, 133-139; Dickie 2001, 54-58.

59 [Dem.] 25.79-80; cf. Aesop. 56 (Perry); Ael. VH 5.18. According to later sources, Theoris was accused of impiety

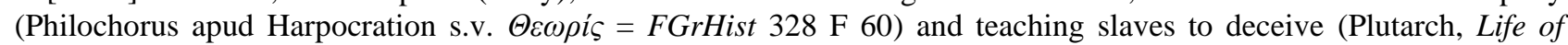
Demosthenes 14.4). See also Collins 2001, 477-479, 486-493; Gordon 1999, 250; Dickie 2001, 50-51; Eidinow 2016: 11-17 and passim. In the fourth century, another female religious practitioner was executed in Athens; although her case probably centered around illicit mystery initiations, the scholia on Demosthenes 19.281 (495a-b Dilts) adds the ministering of love philters to her crime sheet.
} 
that of a spell or incantation, and warns Socrates from travelling out of town as he might be detained as a goês.

During the first centuries of the Common Era, the development of imperial administration made it possible to pursue empire-wide policies and sanctions related to magic. Over the course of time, the prohibitions against magic gradually expanded so that the original ban on evil-intentioned practices came to encompass the practice of magical arts as such, as well as the possession of magical knowledge. The definition of illicit magic was interrelated with private and clandestine rituals, and the accusations of magic were often linked with lese-majesty; in the fourth century CE, magic came to signify objectionable and deviant religion. ${ }^{60}$ During the Roman Republic, however, the criminalization of magic seems to have followed the precedent set by the Greeks. In other words, it was illegal to harm Roman citizens or their property by means of incantations or potions, whereas performing incantations or dispensing potions as such were not proscribed. According to Pliny the Elder (HN 28.4.17-18), the earliest written law, the XII Tables dating to the mid fifth century BCE, forbade enchanting someone's crops to move away (fruges excantassit), and chanting an evil incantation against someone (mala carmen incantassit). ${ }^{61}$ In relation to the former law, Pliny the Elder (HN 18.8.41-43) records a case where a freedman called Gaius Furius Cresimus was accused by his neighbors of conjuring a bountiful harvest at their expense; Cresimus pleaded that his "magic" (veneficia) was simply hard work, and he was consequently acquitted. ${ }^{62}$ Even though Pliny associates the latter law with malicious spells or incantations, Cicero (apud August. De civ. D. 2.9; cf. Cic. Tusc. 4.4; Sen. Sat. 2.1.82-83; Ep. 2.1.152-153), among other later writers, reported that it banned lampooning and defaming others. Thus, as interpreted by James B. Rives (2002, 285-288), it appears that the law sought to protect the Romans from the detrimental effect of words, whether abusive slander or magic spells.

The other well-known republican law sanctioning magic in a strictly limited sense, the Lex Cornelia de sicariis et veneficiis from $81 \mathrm{BCE}$, also primarily criminalized the causing of damage. During his dictatorship, L. Cornelius Sulla reorganized pre-existing laws and court system, and one of his reforms was to issue a law against premeditated homicides and poisonings. The statute was concerned with deaths brought about by stealthy means, the use of venena being one of them. Like Greek pharmaka, the Roman term venena could encompass any natural substances, making no difference

\footnotetext{
${ }^{60}$ See, e.g., Kippenberg 1997, 143, 148-157, 160-162; Rives 2011, 84-103; Collins 2008, 160-163.

${ }^{61}$ See also Sen. Q nat. 4.7.2-3; Apul. Apol.47.3; August. De civ. D. 8.19; cf. Verg. Ecl. 8.95-99. On magic in the XII Tables, see Rives 2002; Kippenberg 1997, 144-146; Gordon 1999, 253-254; Dickie 2001, 142-145; Collins 2008, 142144; Graf 1997, 41-42; Bailliot 2019, 176-179.

${ }^{62}$ See also the discussion of Graf 1997, 62-65.
} 
between poisons or magic potions. In the following centuries, however, the law was brought to bear on the use of malicious ritual actions and other objectionable effects, in addition to death inflicted by medico-magical substances. ${ }^{63}$

According to Valerius Maximus (1.3.3), in 139 BCE the praetor peregrinus Cn. Cornelius Hispanus issued an edict that ordered all Chaldeans to leave Rome and Italy. Chaldeans were experts in astrology, and the stated reason for their expulsion was that they were swindling money out of credulous people with their deceitful prophesies. Ever since the Homeric epic, the inquiry into hidden knowledge had been in the portfolio of miracle workers and sorcerers. In this instance, however, rather than interpreting this as a measure against magical practices, we should view it as a symbolic line drawn between what was considered to be undesirable foreign practices, as opposed to ancestral Roman religion in a more general sense. Tellingly, the Jews were also banished in the same year. Naturally, this was likely to confirm the stereotypical image that certain practices were foreign and marginal. The anxieties over private divination and its methods and intentions were exacerbated during the early Principate, and repeated actions were taken against astrologers (also called mathematici), who were now also paired with magicians. ${ }^{64}$ Nonetheless, the first recorded expulsion was also a demonstration that rituals and inquiry into divine counsels was a public matter, not something to be fiddled about with privately and without sanctioning from the magistrates. This wider discourse is what we shall next turn to.

The absence of clear-cut laws against magical practices demonstrates that those who exercised political, legislative, and judicial power in Greek poleis, Hellenistic kingdoms, and republican Rome were not particularly concerned about the potential perils that practitioners of magic might pose to their own positions, or to the social order at large. ${ }^{65}$ At best, their stance could be described to align with the image of magic as something that happens in the social and geographical periphery, with little or no effect on the center. Many members of the educated elite, however, felt that the activities of and theories promoted by various private religious experts conflicted with their own ideas and objectives. The first mention of magoi by Heraclitus (DK 22 B 14, see above) already subsumed them

\footnotetext{
${ }^{63}$ The Lex Cornelia is discussed in later compilations of Roman law, which assign to it a purview that is apparently much wider than originally intended. See Rives 2006; Rives 2011, 77-82; Kippenberg 1997, 147-148; Gordon 1999, 255-258; Collins 2008, 145-148. Livy $(39.41 .5 ; 40.43 .2-3 ; 40.44 .6)$ relates that an investigation into cases of poisoning that was instigated in $184 \mathrm{BC}$ led to a snowball effect of more and more evidence turning up; before the investigation was abandoned, thousands of people were sentenced to death. Richard Gordon $(1999,254-255)$ has argued that these events contributed to Sulla's decision to establish a permanent commission to hear cases of furtive killings, and to limit the criminalization to the use of venena instead of less tangible incantations.

${ }^{64}$ See, e.g., Cassius Dio (49.43.5) on Agrippa's banishment of astrologers and sorcerers (goêtes) in 33 BCE, and Tacitus (Ann. 2.32) and Cassius Dio (57.15.8) on the measures taken against astrologers and magicians in the reign of Emperor Tiberius in 16/17 CE. See also Gordon 1999, 261-262; Dickie 2001, 153-155; Ogden 2008, 84-85.

${ }^{65} \mathrm{Cf}$. the discussion of Phillips 1991.
} 
in the same category with ecstatic worshippers and mystery initiators; what is more, Heraclitus contrasted their unholy practices with what he considered as proper piety. In other words, Heraclitus effectively establishes the definition of magic as a form of distorted religion that mainly serves private interests.

For those who wished to contest magic there were two main strategies available. First, one could present religio-magical performers as charlatans who performed ineffective conjuring tricks that would work only by chance or as a placebo. This strategy gave the writer a chance to highlight his own expertise and true knowledge. On the other hand, one could present magicians as a genuine threat to the community. This did not necessarily require the author to admit the effectiveness of their rituals; on the contrary, the literati often claimed that it was precisely the magic workers' ungodly and reckless attitude and their desire to deceive people that harmed others and even enraged the gods.

The image of magic as empty hocus-pocus or purposeful deception also appeared in popular genres, suggesting that this was at least one potential way to view magic among the populace. ${ }^{66}$ To portray religious experts as impudent swindlers was therefore an easy way to discredit them. A suggestion that they were solely motivated by hefty fees would further question their competence. As philosophers and medical practitioners started to emerge as a group of self-proclaimed rationalists in the course of the Classical period, they often positioned themselves against religious experts that performed various rituals and dispensed charms for people seeking relief from more-or-less tangible ailments and anxieties. Not only were both opposing groups dependent on the generosity of well-todo supporters and clients, but both also claimed to possess special insights into the workings of the divine world and the human condition. Furthermore, the traditional healers and ritual specialists were often backed by long and prestigious traditions that endowed them with an age-old authority that the philosophers often lacked. ${ }^{67}$

From the Classical period, two examples are especially worth mentioning: the writer of the Hippocratic treatise On the Sacred Disease, usually dated to the second half of the fifth century BCE, and Plato. The Hippocratic writer's vehement attack against healers that use religio-magical rituals evidences a competitive setting between the traditional and emerging branches of medicine. ${ }^{68}$ The treatise tackles the causes of and therapies for epilepsy, which was also known as the sacred disease, and which consequently was seen as the special concern of religious experts. The Hippocratic writer

\footnotetext{
${ }^{66}$ E.g., Eur. Hipp. 1038-1040; Eur. Cyc. 643-653; Aesop. Fab. 56; see also Gordon 1999, 210-212. Naturally, the same person might both believe and disbelieve in magic in different contexts.

${ }^{67}$ See Rauhala 2019, 24-25; Graf 1997, 30-35.

${ }^{68}$ See also the discussions of Lloyd 1979, 15-28, 39-40, 45-49; Martin 2004, 37-46; Collins 2008, 33-42; Collins 2001, 483-484; Dickie 2007, 358-360; Le Person 2009.
} 
castigates the worldview of the healers, which would ascribe the cause of any particular illness to the gods; all diseases follow natural causes and are thus equally divine. The Hippocratic author conjoins himself to a long tradition of philosophical critique that targeted popular and poetic notions of gods, and insisted that the divinity represened moral perfection. Therefore, he rejects the idea that some perfect divinity would enter a flawed human body and pollute it with a disease. As a result, the Hippocratic writer labels his religio-magical rivals as charlatans, and suggests that their ignorance and incompetence are the real reason why they hide behind a divinity's back:

My own view is that those who first attributed a sacred character to this malady were like the magicians, purifiers, beggarpriests and quacks of our own day, men who claim great piety and superior knowledge. Being at a loss, and having no treatment which would help, they concealed and sheltered themselves behind divine causes, and called this illness sacred, in order that their utter ignorance might not be manifest. They added a plausible story, and established a method of treatment that secured their own position. ${ }^{69}$

Furthermore, the Hippocratic writer reproaches the traditional healers for their arrogant claims that, in his view, prove that they are impious and ungodly rather than exceedingly god-fearing:

I am sure that they are impious, and cannot believe that the gods exist or have any strength, and that they would not refrain from the most extreme actions. Wherein surely they are terrible in the eyes of the gods. For if a man by magic and sacrifice will bring the moon down, eclipse the sun, and cause storm and sunshine, I shall not believe that any of these things is divine, but human, seeing that the power of godhead is overcome and enslaved by the cunning of man. But perhaps what they profess is not true, the fact being that men, in need of a livelihood, contrive and devise many fictions of all sorts. ${ }^{70}$

After discrediting his rivals, the Hippocratic writer proceeds to put forward his own explanation for the disease, which - as several scholars have pointed out - is no less inaccurate and fanciful than the one that he rebutted. ${ }^{71}$ What is important to note, however, is that the Hippocratic writer on the one hand bundles religious healers and magicians together, labelling them as impostors who make boastful claims in order to beguile gullible people and thus earn their living. By doing so, he associates

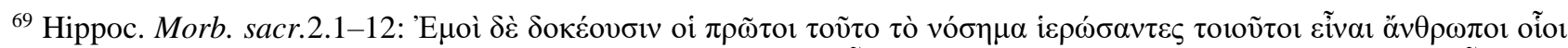

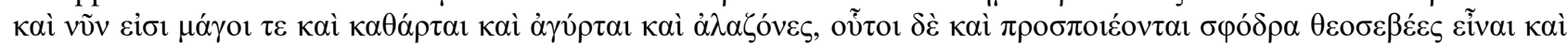

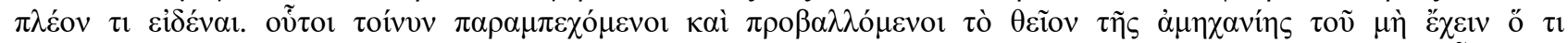

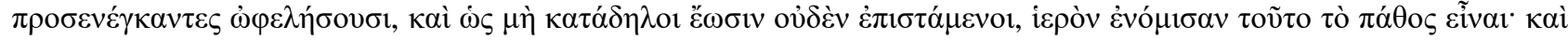

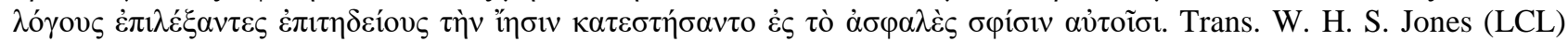
slightly modified.

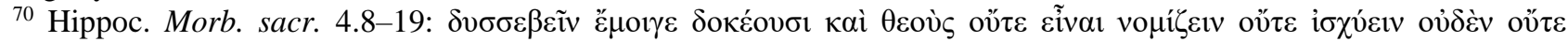

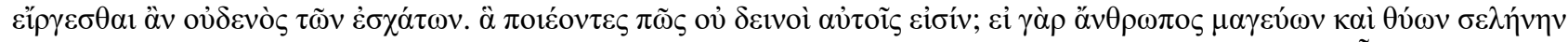

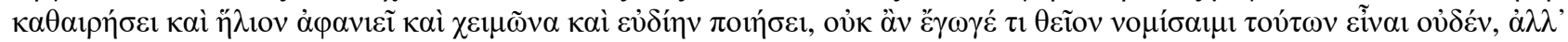

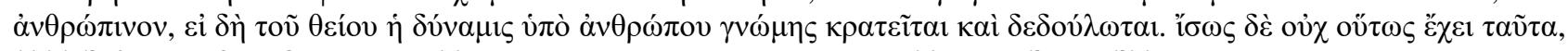

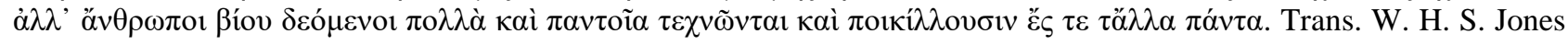
(LCL).

${ }^{71}$ E.g., Lloyd 1979, 20-24, 49; Martin 2004, 42.
} 
himself with the tradition that treats magic as empty but basically harmless nonsense. On the other hand, the writer accuses magicians of impiety, based on their claims to be able to command the gods. As we saw above, impiety was considered a serious offence that was punishable by death, since it might draw divine anger upon the whole community. Thus, the rival practitioners are represented as both incompetent and dangerous at once.

Plato's views on magic and ritual experts offer an interesting parallel to those of the Hippocratic writer. In the famous passage of the Republic, Plato's interlocutor reprimands "beggar-priests and soothsayers" for their claims to be able to exempt people from the consequences of past misdeeds by ritualistic means, as well as to compel the gods with incantations and binding-spells to cause harm to others:

[B]egging priests and soothsayers go to rich men's doors and make them believe that they, by means of sacrifices and incantations, have accumulated a treasure of power from the gods that can expiate and cure with pleasurable festivals any misdeed of a man or his ancestors, and that if a man wishes to harm an enemy, at slight cost he will be enabled to injure the just and unjust alike, since they are masters of spells and enchantments that constrain the gods to serve their end. And for all these sayings they cite the poets as witnesses [...]. And they produce a bushel of books of Musaios and Orpheus, the offspring of the Moon and of the Muses, as they affirm, and these books they use in their ritual, and make not only ordinary men but states believe that there really are remissions of sins and purifications for deeds of injustice, by means of sacrifice and pleasant sport for the living, and that there are also special rites for the deceased, which they call initiations, that deliver us from evils in that other world, while terrible things await those who have neglected to sacrifice. $^{72}$

Like the Hippocratic writer before him, Plato testifies to the intermingling of magicians with other religious experts that were viewed with suspicion. ${ }^{73}$ Undoubtedly, the job description of an itinerant specialist could entail multifarious rituals and performances, but the tendentious bundling of magicians with wandering religious agents highlighted their peripheral status and was likely to intensify the skepticism that one might treat any one of them with. Secondly, Plato clearly voices the sentiment that the magicians and purifiers' pretentions to appease or control the gods are nothing but

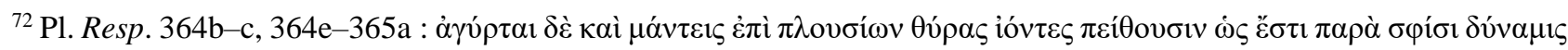

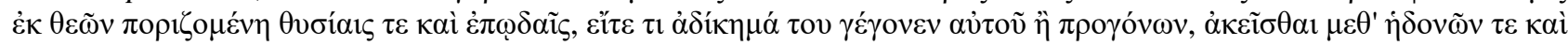

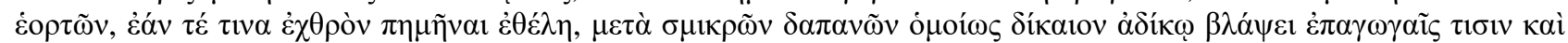

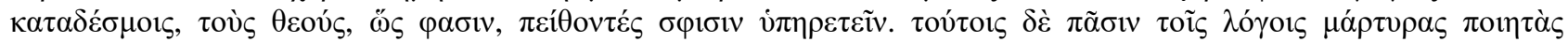

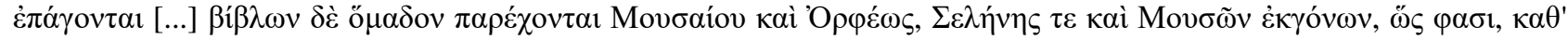

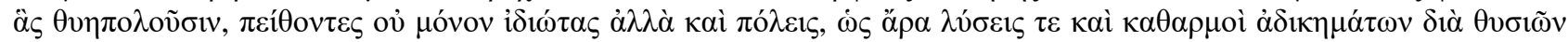

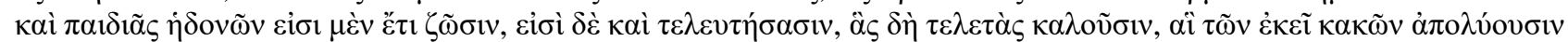

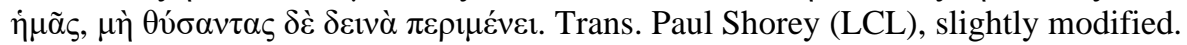

${ }^{73}$ See also Dickie 2001, 61-63, 80; Graf 1997, 21-23. Plato also mentions purifications and initiation rituals in the repertoire of these practitioners, which resembles Heraclitus' association of magoi with various Bacchic worshippers.
} 
malarkey; they seek to sway rich people for personal gain and, as Plato complains, they manage to dupe not only individuals but also entire cities. Thus, he feeds the popular image of magicians as money-grabbing charlatans, ${ }^{74}$ while voicing his discontent with wealthy citizens and poleis that in real life prefer to consult soothsayers and magicians rather than philosophers. ${ }^{75}$

This combination of unscrupulousness and corrupt impiety is even more clearly articulated in Plato's Laws. As Plato outlines the ideal legislation for a polis, he demands harsh punishments for those who hold and promote false ideas about the gods. Whereas those who have impious beliefs about the gods but possess a righteous character may be rehabilitated, among those who deserve an immediate death penalty are various crafty professionals who do not believe in the existence of gods and manage to influence others with their shrewdness. Among these Plato mentions "those who engage in all kinds of magical trickery."76 Plato continues with a passage closely akin to his statement in the Republic; he would imprison and isolate those offenders who "despise men, charming the souls of many of the living, and claiming that they charm the souls of the dead, and promising to persuade the gods by bewitching them, as it were, with sacrifices, prayers and incantations, and who try thus to wreck utterly not only individuals, but whole families and States for the sake of money." 77 In the eleventh book of Laws, Plato returns to the question of law against those who claim to be able to cause injury by "magical arts, incantations, and binding spells." Here, Plato seems to follow to some extent the Athenian law code described above, for he treats these as cases of poisoning ( $\alpha \rho \mu \alpha \dot{\alpha} \varepsilon \varepsilon 1 \alpha)$ and considers that the amount of damage caused should guide the jury in their assessment of suitable punishment. This, however, concerns only laymen who have fiddled with poisons or spells. As the law against impiety already made clear, professionals, whether they are medical practitioners in cases

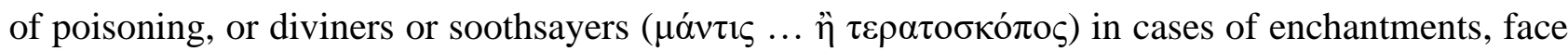
the death penalty. ${ }^{78}$ Therefore, even though Plato pours cold water on the claims of being able to persuade the gods to act unjustly by spells and incantations, ${ }^{79}$ he nevertheless considers that those

\footnotetext{
${ }^{74}$ E.g. Soph. OT 387-389.

${ }^{75}$ See Pl. Resp. 489a-c; cf. Graf 1997, 27.

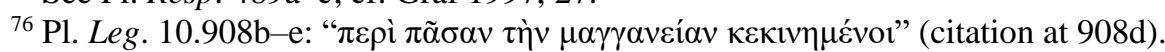

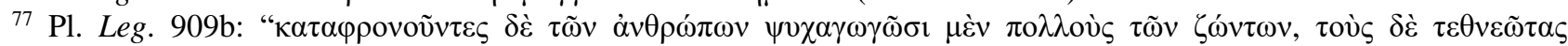

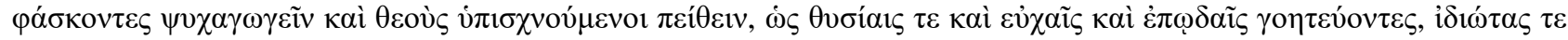

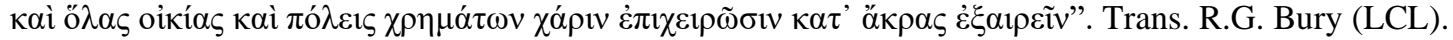

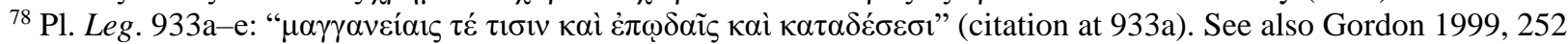

${ }^{79}$ Fritz Graf $(2002$, 97-99) points out that Plato is one of the first thinkers to put forward a theory about the working mechanism of magic. As Plato describes the deterrent effect of the visible signs of magic and the magicians' bold claims that they use to convince people of their powers, he admits that magic is effective on the psychological level. Cf. Gorgias, The Encomium of Helen 10 (DK 82 B 11). See also Graf 1997, 26; Collins 2008, 58-59.
} 
who manipulate people with such allegations are truly dangerous because of the power that they have on others.

The apparently popular stereotype of magicians as wretched hustlers was also employed in the overtly competitive setting of Greek oratory. The suggestion of someone's involvement in magic enterprises was a smoking gun that the rhetorician could brandish in front of the jury as evidence of that person's wickedness and unreliability. ${ }^{80}$ It seems that even vague accusations of magic could be used to discredit one's opponent. ${ }^{81}$ Yet, even though the voices that condemn magic as deception dominate our remaining literary evidence, we can get a glimpse at another discourse that reveals the complexity of the actual situation. Plato's reference to individuals and cities relying on the services of various religious experts already suggests that his voice was but one of many, and not as authoritative as he would have had it. Again, Plato's mention of books as a source of authority for ritual specialists speaks of an alternative tradition that has left us regrettably few traces. Two examples, however, deserve a mention here: the Sicilian pre-Socratic philosopher Empedocles and the anonymous writer of the Derveni papyrus.

Empedocles was born around $490 \mathrm{BCE}$ to an eminent family in Acragas. His philosophy is best known from the fragments of his didactic poems On Nature and Purification, and contained elements, for instance, from the Ionian tradition of natural philosophy and Pythagorean thinking. Yet, the surviving fragments reveal that in many ways his claims resemble those made by the magicians that Plato and the Hippocratic author criticized. Empedocles boldly declared that he was so greatly revered by the people that he was like an immortal god. ${ }^{82}$ He claimed to know remedies for illnesses and aging, ${ }^{83}$ and he asserted that he could master various weather phenomena and summon the spirit of a dead man from Hades. The famous Sophist Gorgias, who had been Empedocles' pupil, had, by his

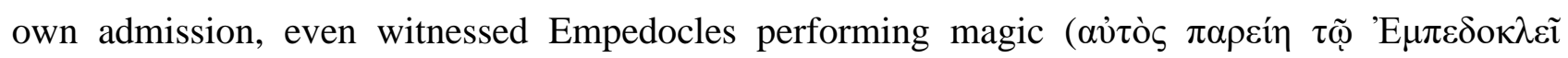

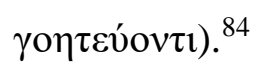

The other notable exception concerns the papyrus scroll found in a fourth-century BCE tomb in Derveni, containing a commentary on Orphic theogony that has been dated to the second half of the fifth century. The writer of the commentary considered himself a professional with a deep knowledge

\footnotetext{
${ }^{80}$ [Dem.] 25.80. See also Dickie 2001, 485-486.

${ }^{81}$ Dem. 18.276; Aeschin. 2.124; 3.137, 207; cf. Dem. 19.109; 29.32.

${ }^{82}$ Empedocles apud Diog. Laert. 8.62 (= DK 31 B 112).

${ }^{83}$ Cf. Eur. Supp. 1109-1110 where the aged Iphis, who has lost his children, longs for death and deplores those who try to prolong their life with food, drinks, or magic spells.

${ }^{84}$ Diog. Laert. 8.59; DK 31 B 111. See also Collins 2008, 52-54; Gordon 1999, 185-186; Kingsley 1995, $218-32$.
} 
and understanding of sacred matters. He sneers at initiators who perform rituals without a sufficient awareness of and ability to transmit the doctrines underlying the rites. ${ }^{85}$ On the other hand, the writer refers to the magoi with respect, and describes the sacrifices and incantations that they use to placate avenging spirits. ${ }^{86}$ The Orphic author seems to identify himself with the magoi to some extent, and he is willing to count them among the informed professionals that he also proudly represented. ${ }^{87}$ Thus, we seem to have a testimony from one of the very professionals that Heraclitus, the Hippocratic author, and Plato disparaged, ${ }^{88}$ and it clearly shows that, at the time, there coexisted different discourses on religio-philosophical knowledge, and that magical art could signify respectful artisanship and authority. ${ }^{89}$ Furthermore, as the position of Empedocles at the interface between magic and philosophy shows, these discourses were in fact were very closely related.

By the Hellenistic period, however, the rationalizing discourse that negated the basis upon which the magicians' claims rested had gained the upper hand. Naturally, it did not mean that either magicians or the discourse that they employed to authorize their practices had suddenly disappeared, nor even that people would have been less inclined to seek their services. It meant, however, that the dominant discourse saw magic as dissociated from communal structures, and any dissonant voices faded into the margins. Nevertheless, the Greek literati were perhaps more than ever interested in exploring and recording magical knowledge, which led to a more uniform and comprehensive idea of magic. ${ }^{90}$

This discourse, which associates magic with a varied set of objectionable practices, is also by and large what we find in the extant Latin literature. ${ }^{91}$ Furthermore, magic appears predominantly in contexts that seek to disrepute its objects. Thus, in the speech Against Vatinus (14), Cicero denigrates his opponent with the negative imagery associated with magic, but never actually calls him a magician. According to Cicero, Vatinius' hid his corrupt and impious behavior behind the guise of Pythagoreanism - which in itself was a philosophical sect with many suspicious features. ${ }^{92}$ Cicero describes Vatinius' habits as savage and barbarian (immanibus et barbaris moribus), thus emphasizing their marginality and foreignness to Roman ways, and claims that Vatinius defies the

\footnotetext{
${ }^{85}$ P Derv. col. 20 (col 60 Janko/Kotwick).

${ }^{86}$ P Derv. col. 6 (col. 46 Janko/Kotwick).

${ }^{87}$ See Betegh 2004, 80-82, 352-355, 360-363; Edmonds 2013, 129-135.

${ }^{88}$ Cf. Graf 2019, 118-119.

${ }^{89}$ Otto $(2013,325-327$ and passim) calls this this self-referential use of magos the discourse of inclusion (the only example of which he identifies the Greek magical papyri), as opposed to the discourse of exclusion, which dominates the vast majority of ancient sources and employs the concept of magic as a polemical tool of social exclusion.

${ }^{90}$ Richard Gordon $(1999,229-231)$ has called this the strong view of magic; see also above with n. 34.

${ }^{91}$ Before the first century CE, however, Roman authors do not yet employ any umbrella terms for "magic" that would evoke a range of objectionable practices, as was the case in Greek literature. On the development of the Roman concept, see Graf 1997, 48-57.

${ }^{92}$ Cf. Varro apud August. De civ. D. 7.35.
} 
auspices, which form the basis of the Roman Republic. Cicero bolsters his allegations with vague references that strongly suggested the polemical concept of magic: Vatinius is involved in unprecedented and impious rites (inaudita ac nefaria sacra), and he is wont to conjure up the spirits of the dead and placate the Manes with the entrails of young boys (cum inferorum animas elicere, cum puerorum extis deos manis mactare soleas). ${ }^{93}$ In other words, the unfavorable imagery associated with magic works as a weapon in agonistic contexts where it appears as a perverse form of proper religion that endangers the foundations of the society.

Even though high-ranking Romans probably consulted magic workers and various itinerant specialists, just as wealthy members of the Greek elite had done despite the murmurs of philosophers, ${ }^{94}$ such activities could tarnish not only the practitioners themselves but also those using their services. Thus, Lucan casts a slur on Sextus Pompeius, the son of the famed general Pompey the Great, based on his involvement in the type of necromancy that allegedly required the use of murdered boys. Even though the rite is performed by the aforementioned gruesome witch Erichtho, it echoes the fearful and weak nature of the military leader. As the Civil War rages on, an anxious Pompeius wants to find out what lies ahead and, instead of seeking advice from respectable oracles or lawful divination, he turns to the Thessalian witch. According to Lucan, "[t]o him were known the mysteries of cruel witchcraft which the gods above abominate, and grim altars with funeral rites; he knew the veracity of Pluto and the shades below; and the wretch was convinced that the gods of heaven are ignorant." $" 95$ Lucan suggests that Pompeius' choice already disclosed his own inclination to shady magical practices that are unequivocally represented as the opposite of licit religion. ${ }^{96}$ Even though we cannot extend Lucan's first-century CE view on magic to Pompeius' own time, his description may well reveal a late Republican accusation that was used to harm the reputation of Pompeius. After all, he had continued his father's battle against Julius Caesar and formed the last notable opposition against the Second Triumvirate. Therefore, it is feasible that propaganda against Pompeius would have been transmitted after his death and, as Lucan implies, magic was an integral part of it.

\section{Conclusion: Othering Magic}

The discourse on magic effectively revolves around otherness and contested authority. In the modern research, magic is often defined by exclusion. The involvement of superhuman powers naturally placed "magic" in the same semantic field with "religion", and after one had defined - often based

\footnotetext{
${ }^{93}$ Cic. Vat. 14; see also Dickie 2001, 137-138, 170; Graf 1997, 39-40; Gordon 1999, 207.

${ }^{94}$ See Cato, Agr. 5.4; Apul. Apol. 42; Graf 1997, 84-85.

${ }^{95}$ Luc. 6.430-434: "Ille supernis/ Detestanda deis saevorum arcana magorum/ Noverat et tristes sacris feralibus aras,/ Umbrarum Ditisque fidem, miseroque liquebat/ Scire parum superos."

${ }^{96}$ See Dickie 2001, 174-175.
} 
on Western Judeo-Christian ideas about religion - what constitutes "religion", "magic" came to signify practices that fell outside this framework. On the other hand, the invocation of the working mechanisms of the natural world associated "magic" with "science" and, again, once the theorizing that met the requirements of the modern conception of science were sorted out, "magic" was reserved to denote defective rationalization. Thus, the research tradition that has shaped our understanding of magic has considered it as either a primitive form of religion, an irreverent and self-seeking manipulation of higher forces, or false science. In recent decades, this approach, which strongly rested on etic notions, has been questioned from various quarters. Some scholars have even called for keeping to the sole use of emic concepts. Should we, thus, abandon the value-laden term "magic" and simply talk about various ritual actions?

"Magic" is a useful and even necessary etic concept when one analyzes Greco-Roman magic, but it needs to be defined with precision in order to avoid any unvoiced cultural conceptions impinging on the interpretation of ancient sources. Yet, magic was also an emic concept that both the Greek and Roman writers employed in different contexts. The inherent otherness associated with the concept of magic is also pervasive in the surviving Greco-Roman literature. The Ephesian philosopher Heraclitus contrasted certain private practitioners and their rites with proper religion already at the turn of the Classical period; in all probability these included magicians. Likewise, Plato vehemently condemned magicians' fraudulent practices as an impious desecration of the gods. The writer of the Hippocratic treatise On the Sacred Disease did not hesitate to reproach the impiety of magicians and refute their claims while trumpeting his own, supposedly more learned views on the nature. Thus, the dichotomies between magic and religion, on the one hand, and between magic and science, on the other, had taken shape already in the fifth century BCE. ${ }^{97}$ The ideas of magic as deception, as an irreverent bid to compel the gods, and as a means to seek personal gain as opposed to communal good, would have been familiar to Greeks and Romans before the Common Era. Therefore, magic as a discourse that created distance, marginalization, and otherness is a useful and even necessary tool in current scholarship. As Robert L. Fowler $(2000,341)$ put it: "the contexts in which denunciations of magic occur, and the criteria by which the denouncer hopes to persuade his peers that the charge is founded, become more interesting and revealing than what is actually called magic."

When one surveys the contexts of these denunciations, one noteworthy setting stands out. In the words of Alan F. Segal (1981, 370): “The charge of magic is likely to be made by legitimate religious leaders against people who are viewed as threatening the social order but who have as yet done no other

\footnotetext{
${ }^{97}$ See also Graf 1997, 27, 35.
} 
criminal offence." In other words, the association with magic is often evoked in situations where someone seeks to deny the authority of a religious practitioner whose activities fall beyond the confines of officially endorsed cults and ritual actions. Therefore, magic was closely interrelated with mystery initiations, purifications, and, especially in Rome, with unsanctioned modes of divination. The ruling elite of Greek poleis, Hellenistic kingdoms, and the Roman Republic also exercised religious power, and they ultimately had control over legitimate religious knowledge and the various rituals that were associated with state structures. Anyone who claimed to have special religious knowledge outside this framework posed a potential threat to the authorities and was, thus, liable to accusations of illegitimate power. ${ }^{98}$ As a consequence, the dominant discourse that validated the established order represented magic as marginal and devious. The negative connotations of magic were so strong that philosophers and medical practitioners, whose authority might be equally contested, resorted to insinuations of magic in order to discredit their rivals.

Lastly, we need to remember that the image that the dominant Greco-Roman discourse constructed on magic was not the only possible one. Those who practiced rituals that were regularly labeled as magic in a depreciative sense might also employ the vocabulary of magic and magicians as an attestation of their expertise and power. Instead of being barbaric nonsense, magic could equally well denote ancient Eastern wisdom; it could signify powerful rituals and hidden knowledge rather than deceit and dubious tricks. Therefore, in addition to scrutinizing magic as a discursive tool that was used to communicate the limits of acceptable religious power, modern scholars also need to consider the concept of magic as it might have been used by those who considered themselves to be religious specialists and magicians. Magic meant real ritual power for many religious professionals and their clients.

\section{Bibliography}

Bailliot, M., "Rome and the Roman Empire," in D. Frankfurter (ed.), Guide to the Study of Ancient Magic (RGRW 189; Leiden/Boston: Brill, 2019), 175-197.

Bremmer, J. N., “The Birth of the Term 'Magic,” ZPE 126 (1999) 1-12.

Collins, D., "Theoris of Lemnos and the Criminalization of Magic in Fourth-Century Athens," $C Q$ 51.2 (2001) 477-493.

Collins, D., Magic in the Ancient Greek World (Malden: Blackwell Publishing, 2008).

\footnotetext{
${ }^{98}$ Cf. Gordon 1999, 193-194; Stratton 2007, 62.
} 
Dickie, M. W., Magic and Magicians in the Greco-Roman World (London: Routledge, 2001).

Dickie, M. W., "Magic in Classical and Hellenistic Greece," in D. Ogden (ed.), A Companion to Greek Religion (Malden: Blackwell, 2007), 357-370.

Durkheim, É., The Elementary Forms of the Religious Life, trans. J. W. Swain (London: George Allen \& Unwin, 1915).

Edmonds, R. G. III, Redefining Ancient Orphism: A Study in Greek Religion (Cambridge: Cambridge University Press, 2013).

Eidinow, E., Envy, Poison, and Death: Women on Trial in Classical Athens (Oxford: Oxford University Press, 2016).

Eidinow, E., "Magic and Social Tension," in D. Frankfurter (ed.), Guide to the Study of Ancient Magic (RGRW 189; Leiden/Boston: Brill, 2019), 746-774.

Fowler, R. L., "Greek Magic, Greek Religion,” in R. Buxton (ed.), Oxford Readings in Greek Religion (Oxford: Oxford University Press, 2000), 317-343. .

Frankfurter, D., “The Social Context of Women's Erotic Magic in Antiquity,” in D. S. Kalleres and K. B. Stratton (eds.), Daughters of Hecate: Women and Magic in the Ancient World (Oxford: Oxford University Press, 2014), 319-339.

Frankfurter, D., “Ancient Magic in a New Key: Refining an Exotic Discipline in the History of Religions," in D. Frankfurter (ed.), Guide to the Study of Ancient Magic (RGRW 189; Leiden/Boston: Brill, 2019), 3-20.

Frazer, J. G., The Golden Bough: A Study in Magic and Religion, Vol. 1, $2^{\text {nd }}$ revised and enlarged edition (London: MacMillan, 1900 [1890]).

Goode, W. J., Religion among the Primitives (Glencoe: The Free Press, 1951).

Gordon, R. L., “Imagining Greek and Roman Magic,” in V. Flint, R. Gordon, G. Luck, and D. Ogden (eds.), Witchcraft and Magic in Europe: Ancient Greece and Rome, The Athlone History of Witchcraft and Magic in Europe 2 (London: Athlone Press, 1999), 159-275.

Gordon, R. L., and Marco Simón, F., "Introduction," in R. L. Gordon and F. Marco Simón (eds.), Magical Practice in the Latin West: Papers from the International Conference Held at the University of Zaragoza, 30 Sept.-1 Oct. 2005 (Leiden/Boston: Brill, 2010), 1-49.

Graf, F., "Prayer in Magical and Religious Ritual," in Ch. A. Faraone and D. Obbink (eds.), Magica Hiera: Ancient Greek Magic and Religion (Oxford: Oxford University Press, 1991), $188-213$.

Graf, F., Magic in the Ancient World, trans. F. Philip (Cambridge: Harvard University Press, 1997). Graf, F., "Theories of Magic in Antiquity," in P. Mirecki and M. Meyer (eds.), Magic and Ritual in the Ancient World (RGRW 141; Leiden/Boston: Brill, 2002), 92-104. 
Graf, F., "Greece," in D. Frankfurter (ed.), Guide to the Study of Ancient Magic (RGRW 189; Leiden/Boston: Brill, 2019), 115-138.

Hall, E., Inventing the Barbarian: Greek Self-Definition through Tragedy (Oxford: Clarendon Press, 1989).

Kahlos, M., Debate and Dialogue: Christian and Pagan Cultures, c. 360-430 (Aldershot: Ashgate, 2007).

Kahlos, M., "Artis heu magicis - The Label of Magic in the Fourth-Century Disputes and Conflicts," in M. R. Salzman, M. Sághy, and R. Lizzi Testa (eds.), Pagans and Christians in Late Antique Rome (Cambridge: Cambridge University Press, 2015), 162-177.

Kippenberg, H. G., "Magic in Roman Civil Discourse: Why Rituals Could Be Illegal,” in P. Schäfer and H. G. Kippenberg (eds.), Envisioning Magic: A Princeton Seminar and Symposium. (SHR 75; Leiden/Boston: Brill, 1997), 137-163.

Le Person, G., "Soigner l'épilepsie (Hippocrate, Maladie sacrée). Existe-t-il une opposition entre la médicine 'populaire' des magoi et la médicine 'rationnelle' des Hippocratiques dans le traitement de la maladie?” in . L. Bodiou, V. Mehl, J. Oulhen, F. Prost, and J. Wilgaux (eds.), Chemin faisant: Mythes, cultes et société en Grèce ancienne: Mélanges en l'honneur de Pierre Brulé (Rennes: Presses Universitaires de Rennes, 2009), 285-295.

Lloyd, G. E. R., Magic, Reason and Experience: Studies in the Origins and Development of Greek Science (Cambridge: Cambridge University Press, 1979).

Malinowski, B., Magic, Science and Religion and Other Essays, ed. R. Redfield (Boston: Beacon Press, 1948).

Martin, D. B., Inventing Superstition: From the Hippocratics to the Christians (Cambridge: Harvard University Press, 2004).

Ogden, D., Night's Black Agents: Witches, Wizards and the Dead in the Ancient World (London/New York: Hambledon Continuum, 2008).

Otto, B.-Ch., “Towards Historicizing 'Magic' in Antiquity,” Numen 60.2-3 (2013) 308-347.

Phillips, C. R. III, “Nullum Crimen sine Lege: Socioreligious Sanctions on Magic,” in Ch. A. Faraone and D. Obbink (eds.), Magica Hiera: Ancient Greek Magic and Religion (Oxford: Oxford University Press, 1991), 260-276.

Rauhala, M., "Arresting Alternatives: Religious Prejudice and Bacchantic Worship in Greek Literature," Numen 66.1 (2019) 1-55.

Remus, H., “"Magic,' Method, Madness,” Method \& Theory in the Study of Religion 11.3 (1999) $258-298$.

Rives, J. B., "Magic in the XII Tables Revisited,” CQ 52.1 (2002) 270-290. 
Rives, J. B., "Magic, Religion, and Law: The Case of the Lex Cornelia de sicariis et veneficiis," in C. Ando and J. Rüpke (eds.), Religion and Law in Classical and Christian Rome (PAwB 15; Stuttgart: Franz Steiner, 2006), 47-67.

Rives, J. B., "Magus and its Cognates in Classical Latin,” in R. L. Gordon and F. Marco Simón (eds.), Magical Practice in the Latin West: Papers from the International Conference Held at the University of Zaragoza, 30 Sept. - 1st Oct. 2005 (RGRW 168; Leiden/Boston: Brill, 2010), 53-77.

Rives, J. B., "Magic in the Roman Law: The Reconstruction of a Crime," J. A. North and S. R. F. Price (eds.), The Religious History of the Roman Empire: Pagans, Jews, and Christians (Oxford: Oxford University Press, 2011), 71-108.

Sanzo, J. E., "Early Christianity," in D. Frankfurter (ed.), Guide to the Study of Ancient Magic (RGRW 189; Leiden/Boston: Brill, 2019), 198-239.

Sanzo, J. E., "Deconstructing the Deconstructionists: A Response to Recent Criticisms of the Rubric 'Ancient Magic,"” in A. Mastrocinque, J. E. Sanzo, and M. Scapini (eds.), Ancient Magic: Then and Now (PAwB 74; Stuttgart: Franz Steiner, 2020) 25-46.

Scarborough, J., "The Pharmacology of Sacred Plants, Herbs, and Roots," in Ch. A. Faraone and D. Obbink (eds.), Magica Hiera: Ancient Greek Magic and Religion (Oxford: Oxford University Press, 1991), 138-174.

Segal, A. F., "Hellenistic Magic: Some Questions of Definition," in R. van den Broek and M. J. Vermaseren (eds.), Studies in Gnosticism and Hellenistic Religions Presented to Gilles Quispel on the Occasion of his 65th Birthday (EPRO 91; Leiden/Boston: Brill, 1981), 349-375.

Spaeth, B. S., "From Goddess to Hag: The Greek and the Roman Witch in Classical Literature," in D. S. Kalleres and K. B. Stratton (eds.), Daughters of Hecate: Women and Magic in the Ancient World (Oxford: Oxford University Press, 2014), 41-70.

Stratton, K. B., Naming the Witch: Magic, Ideology, and Stereotype in the Ancient World (New York: Columbia University Press, 2007).

Stratton, K. B., "Interrogating the Magic-Gender Connection," in D. S. Kalleres and K. B. Stratton (eds.), Daughters of Hecate: Women and Magic in the Ancient World (Oxford: Oxford University Press, 2014a), 1-37.

Stratton, K. B., "Magic, Abjection, and Gender in Roman Literature," in. D. S. Kalleres and K. B. Stratton (eds.), Daughters of Hecate: Women and Magic in the Ancient World (Oxford: Oxford University Press, 2014b), 152-180. 
Tylor, E. B., Primitive Culture: Researches into the Development of Mythology, Philosophy, Religion, Language, Art and Custom, Vol. 1, $3^{\text {rd }}$ revised edition (London: John Murray, 1891 [1865]).

Versnel, H. S., "Beyond Cursing: The Appeal to Justice in Judicial Prayers," in Ch. A. Faraone and D. Obbink (eds.), Magica Hiera: Ancient Greek Magic and Religion (Oxford: Oxford University Press, 1991a), 60-106.

Versnel, H. S., "Some Reflections on the Relationship Magic-Religion,” Numen 38.2 (1991b) 177197.

Wax, M., and Wax, R., “The Notion of Magic," Current Anthropology 4.5 (1963) 495-518.

Winkler, J. J., "The Constraints of Eros," in Ch. A. Faraone and D. Obbink (eds.), Magica Hiera: Ancient Greek Magic and Religion (Oxford: Oxford University Press, 1991), 214-243. 